\title{
Staphylococcus aureus expresses a cell surface protein that binds both IgG and $\beta_{2}$-glycoprotein I
}

\author{
Lihong Zhang, Karin Jacobsson, Katrin Ström, † Martin Lindberg \\ and Lars Frykberg
}

\begin{abstract}
Author for correspondence: Lars Frykberg. Tel: +46186732 99. Fax: +4618673392.
\end{abstract} e-mail : Lars.Frykberg@mikrob.slu.se

Department of

Microbiology, Swedish

University of Agricultural

Sciences, SE-750 07 Uppsala, Sweden

\begin{abstract}
The existence of a second IgG-binding protein, protein Sbi, in Staphylococcus aureus has been reported previously. Later data indicated that protein Sbi also bound another serum component. This component has now been affinitypurified on immobilized protein Sbi and identified as $\beta_{2}$-glycoprotein I $\left(\boldsymbol{\beta}_{2}\right.$-GPI), also known as apolipoprotein H. The minimal $\beta_{2}$-GPI-binding domain was identified by shotgun phage display and the binding was shown to be mediated by a region of 57 amino acids, clearly separated from the IgGbinding domain. It is also shown that protein Sbi, and thus the $\boldsymbol{\beta}_{2}$-GPI-binding activity, is expressed on the staphylococcal cell surface at levels varying between strains.
\end{abstract}

Keywords: Sbi, $\beta_{2}$-glycoprotein I (apolipoprotein H), Staphylococcus aureus, IgG, phage display

\section{INTRODUCTION}

Stapbylococcus aureus is a member of the human commensal flora. However, if mucosal barriers are breached or host immune defences are impaired, $S$. aureus can cause a variety of diseases in humans and animals, including wound sepsis, osteomyelitis, endocarditis and mastitis. With the widespread use of antimicrobials, the incidence and spread of highly antibiotic-resistant, especially methicillin-resistant $S$. aureus strains (MRSA), have increased rapidly in recent years, and constitute a clinical and epidemiological problem in hospitals all over the world (Swartz, 1994). To enable the development of preventive and therapeutical measures, investigations of interactions between the bacterium and the host are required.

$S$. aureus strains export a number of potential virulence factors into the surroundings, e.g. alpha-, beta-, deltaand gamma-toxins, toxic shock syndrome toxin, enterotoxins, lipase, coagulase and proteases (Cunningham et al., 1996). The bacterium is also known to express adhesins which bind to host matrix and plasma proteins, e.g. fibronectin, fibrinogen, collagen, bone sialoprotein,

†Present address: Department of Pharmaceutical Biosciences, Uppsala University, Box 581, SE-751 23 Uppsala, Sweden.

Abbreviations: $\beta_{2}$-GPI, $\beta_{2}$-glycoprotein I; HRP, horseradish peroxidase; NCS, newborn calf serum. vitronectin and immunoglobulins (Cunningham et al., 1996). The binding of $\operatorname{IgG}$ is a common property among pathogenic Gram-positive cocci and the IgG-binding protein protein A (SpA; Uhlén et al., 1984) is one of the most studied surface proteins of $S$. aureus. However, it has not been proven that protein $\mathrm{A}$ is of major importance for virulence since spa-negative mutants are only slightly less virulent than the parent bacteria (Jonsson et al., 1985; Patel et al., 1987). Recently, we reported the existence of a second IgG-binding protein (Sbi) in S. aureus (Zhang et al., 1998).

We have shown that shotgun phage display can be used for cloning of genes encoding bacterial adhesins by panning against host proteins (Jacobsson \& Frykberg, 1995, 1996, 1998). Recently, panning a phage display library made from $S$. aureus chromosomal DNA against newborn calf serum (NCS) resulted in detection of not only known interactions, but also a novel interaction (Jacobsson \& Frykberg, 1998). The majority of the clones isolated after panning against NCS encoded IgGbinding or fibronectin-binding polypeptides. However, most of the other clones contained different overlapping DNA fragments derived from the sbi gene. Interestingly, the inserts did not encode the part of protein Sbi that mediates the IgG-binding activity, which strongly suggested that protein Sbi bound a second serum component in addition to IgG. This protein has now been isolated from serum by affinity chromatography 
and identified as $\beta_{2}$-glycoprotein I ( $\beta_{2}$-GPI, also called apolipoprotein $\mathrm{H})$.

\section{METHODS}

Bacterial strains, vector and helper phage. Restriction and modifying enzymes were from Amersham or MBI Fermentas.

Escherichia coli strain MC1061 (Wertman et al., 1986) was used for production of fusion protein and E. coli strain TG1 (Sambrook et al., 1989) for production of phage stocks. Both strains were cultivated in Luria-Bertani (LB) broth or on LA plates (LB broth with $1.5 \%, \mathrm{w} / \mathrm{v}$, agar) and when required supplied with $50 \mu \mathrm{g}$ ampicillin $\mathrm{ml}^{-1}$. Phage R408 (Promega) was used as helper phage. Staphylococcal strains 8325-4, Wood 46, Newman 4 and Cowan I (NCTC 8350) were grown in TSB (Tryptic Soya Broth; Oxoid). Staphylococcus epidermidis 247 (Rosendorf \& Kayser, 1974) containing the shuttle plasmid pShX1 (Zhang et al., 1998) was grown in TSB supplied with $20 \mu \mathrm{g}$ chloramphenicol $\mathrm{ml}^{-1}$. S. aureus strain $8325-4$ is NCTC 8325 cured of prophages (Novick, 1967). Wood 46 is a protein-A-negative reference strain (Kronvall $e t$ al., 1970) and Newman 4 is a spontaneous mutant of strain Newman with enhanced production of fibronectin-binding protein (Jönsson et al., 1991).

The pG8SAET phagemid vector is a derivative of the pG8SPA1 vector (Jacobsson \& Frykberg, 1998), in which the serumalbumin-binding domain has been exchanged for the E-tag (Pharmacia Biotech). The oligonucleotides E-tagS 5' GGT GCG CCG GTG CCG TAT CCG GAC CCA CTG GAA CCG CGT GCC TAG G 3' and E-tagR 5' GAT CCC TAG GCA CGC GGT TCC AGT GGG TCC GGA TAC GGC ACC GGC GCA CC 3' were synthesized by Pharmacia Biotech. The pG8SPA1 vector was digested with BamHI and Smal to remove the region encoding the albumin-binding domain and ligated with the oligonucleotides using the ReadyTo-Go ligation kit from Pharmacia Biotech.

Antibodies. Antibodies against MAL-Sbi (aa 33-436 in protein Sbi,; Zhang et al., 1998) developed in chicken were obtained through Immunsystem (four repeated immunizations with $50 \mu \mathrm{g}$ MAL-Sbi). The antibodies were affinity-purified on MAL-Sbi, immobilized on CNBr-activated Sepharose $4 \mathrm{~B}$ (Pharmacia Biotech) and labelled with horseradish peroxidase (HRP) (Boehringer Mannheim). Rabbit polyclonal antibodies against human $\beta_{2}$-GPI were from Chemicon International and HRP-labelled goat anti-rabbit antibodies were from Santa Cruz Biotechnology. The mAb against the E-tag was from Pharmacia Biotech and the HRP-labelled horse anti-mouse antibodies were from Vector Laboratories.

Serum protein purification and $\mathrm{N}$-terminal amino acid sequencing. MAL-Sbi $\Delta$ fusion protein, lacking the IgGbinding region (aa 1-143), was purified on an amylose resin as described by Zhang et al. (1998). MAL-Sbi $\Delta$ (10 mg) was coupled to $0.5 \mathrm{~g}$ dry $\mathrm{CNBr}$-activated Sepharose $4 \mathrm{~B}$ according to the manufacturer's instructions. The $4.5 \mathrm{ml}$ column was equilibrated with $20 \mathrm{mM}$ Tris $/ \mathrm{HCl}, \mathrm{pH} 7 \cdot 4$, with $0 \cdot 2 \mathrm{M} \mathrm{NaCl}$, whereafter $10 \mathrm{ml}$ NCS (Life Technologies) was passed over the column. After washing with the same Tris $/ \mathrm{HCl}$ buffer until a steady baseline was obtained, the bound protein was eluted in $6 \mathrm{ml} 0.25 \mathrm{M}$ acetic acid, $\mathrm{pH} 2 \cdot 2$. After extensive dialysis against distilled $\mathrm{H}_{2} \mathrm{O}$ the eluted proteins were lyophilized and dissolved in $100 \mu \mathrm{l}$ PBS-D (140 mM NaCl, $\left.8 \mathrm{mM} \mathrm{Na}_{2} \mathrm{HPO}_{4}, 1.7 \mathrm{mM} \mathrm{KH}_{2} \mathrm{PO}_{4}, 2.7 \mathrm{mM} \mathrm{KCl}, \mathrm{pH} 7 \cdot 4\right)$. The $\mathrm{N}$-terminal amino acid sequence was determined using the Applied Biosystems 476A Protein Sequencer according to the manufacturer's instructions. The SWISS-PROT and PIR databases were searched for sequence homologies.

The same protocol was also used for purification of the serum component from human and rat serum.

Electrophoresis and Western blotting. Proteins purified from bovine, human and rat serum were analysed by non-reducing SDS-PAGE using the Phast system (Pharmacia Biotech) with PhastGel Gradient 8-25\% (w/v) gels and PhastGel SDS Buffer Strips. Purified protein $(2 \mu \mathrm{l})$ was mixed with $2 \mu \mathrm{l} 2 \times$ sample buffer $(1 \times$ buffer $=62.5 \mathrm{mM}$ Tris $/ \mathrm{HCl}, \mathrm{pH} 6.8 ; 10 \%, \mathrm{v} / \mathrm{v}$, glycerol; $2 \%, \mathrm{w} / \mathrm{v}, \mathrm{SDS}$; and $0.01 \%, \mathrm{w} / \mathrm{v}$, bromophenol blue), boiled for $2 \mathrm{~min}$, after which $1 \mu \mathrm{l}$ was loaded on the gel. As a positive control, $0.2 \mu \mathrm{g}$ commercially available human apolipoprotein $\mathrm{H}$ (ICN Pharmaceuticals) was used. The gels were run in duplicate and the proteins were blotted onto nitrocellulose filters (Schleicher \& Schuell). Protein was detected using either rabbit polyclonal antibodies against human $\beta_{2}$-GPI and HRP-labelled goat anti-rabbit antibodies, or MAL-Sbi $\left[15 \mu \mathrm{g} \mathrm{m} l^{-1}\right.$ in PBS-T (PBS-D containing $0.05 \%$, $\mathrm{v} / \mathrm{v}$, Tween 20)] and HRP-labelled antibodies against MALSbi. Bound antibodies were detected with 4-chloro-1-naphthol (Serva).

Identification of the $\boldsymbol{\beta}_{2}$-GPI-binding domain. A gene fragment phage display library was constructed essentially as described by Jacobsson \& Frykberg (1995). In short, DNA from plasmid pPX1 (pUC18 containing the cloned sbi gene; Zhang et al., 1998) was sonicated until fragments from $0 \cdot 1$ to $1 \mathrm{~kb}$ in size were obtained. The fragments were made blunt-ended and, using the Ready-To-Go ligation kit (Pharmacia Biotech), were ligated into the gene-VIII-based phagemid pG8SAET, previously digested with $S n a B I$ and dephosphorylated with calf intestine alkaline phosphatase. Electrotransformation into $E$. coli strain TG1 yielded $8 \times 10^{5}$ individual transformants, and after infection with helper phage, the final library had a titre of $1 \times 10^{11}$ c.f.u. $\mathrm{ml}^{-1}$

Two hundred microlitre portions of the library were panned against $\mathrm{NCS}$ (diluted $1 / 20$ in $50 \mathrm{mM} \mathrm{NaHCO}, \mathrm{pH} 9 \cdot 7$ ) or human $\beta_{2}$-GPI $\left(10 \mu \mathrm{g} \mathrm{ml}^{-1}\right)$ immobilized in microwells as described earlier (Jacobsson \& Frykberg, 1995). Pannings against NCS were carried out in the presence of human IgG (100 $\mu \mathrm{g} \mathrm{ml}^{-1}$; Kabivitrum) to inhibit the enrichment for IgGbinding phage. Colonies obtained after infection of $E$. coli TG1 with the phage particles eluted at $\mathrm{pH} 2.0$ were screened for expression of the E-tag using an $\mathrm{mAb}$ against the E-tag and a HRP-labelled horse anti-mouse antibody. Plasmid DNA was isolated from clones expressing the E-tag using the Qiaprep Miniprep kit (Qiagen). The nucleotide sequence of the inserted DNA was determined with the Thermo Sequenase dye terminator cycle sequencing kit from Amersham and the samples were analysed using the ABI 377 DNA Sequencer (Perkin Elmer).

Separation of the IgG- and $\boldsymbol{\beta}_{2}$-GPI-binding domains. Phage stocks were made from clones SbiS12 and SbiS13 (Fig. 1) as described previously (Zhang et al., 1998) and the titres were adjusted to $5 \times 10^{8}$ c.f.u. $\mathrm{ml}^{-1}$. The stocks were panned against human IgG, $\beta_{2}$-GPI and fibronectin (Sigma), coated at concentrations of $10 \mu \mathrm{g} \mathrm{ml}^{-1}$, as described by Jacobsson \& Frykberg (1995). The number of bound phagemid particles was determined as c.f.u. after infection of $E$. coli TG1 cells with the phage eluted at $\mathrm{pH} 2 \cdot 0$.

Binding of ${ }^{125}$ I-labelled $\beta_{2}$-GPI and anti-Sbi antibodies to different $S$. aureus strains. Human $\beta_{2}$-GPI was ${ }^{125} \mathrm{I}$-labelled according to Bolton \& Hunter (1973) using the Bolton + Hunter reagent from Amersham. Anti-Sbi antibodies 
(a)

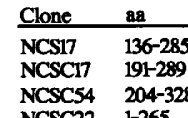

(b)

\begin{tabular}{ll} 
SbiS6 & $204-284$ \\
SbiS8 & $128-266$ \\
\hline SbiS12 & $20-109$ \\
SbiS13 & $196-293$ \\
SbiS27 & $125-286$ \\
& \\
& \\
SbiA8 & $204-284$ \\
SbiA49 & $196-293$ \\
SbiA94 & $192-261$ \\
SbiA96 & $124-287$ \\
SbiA105 & $196-282$ \\
SbiA155 & $202-261$
\end{tabular}
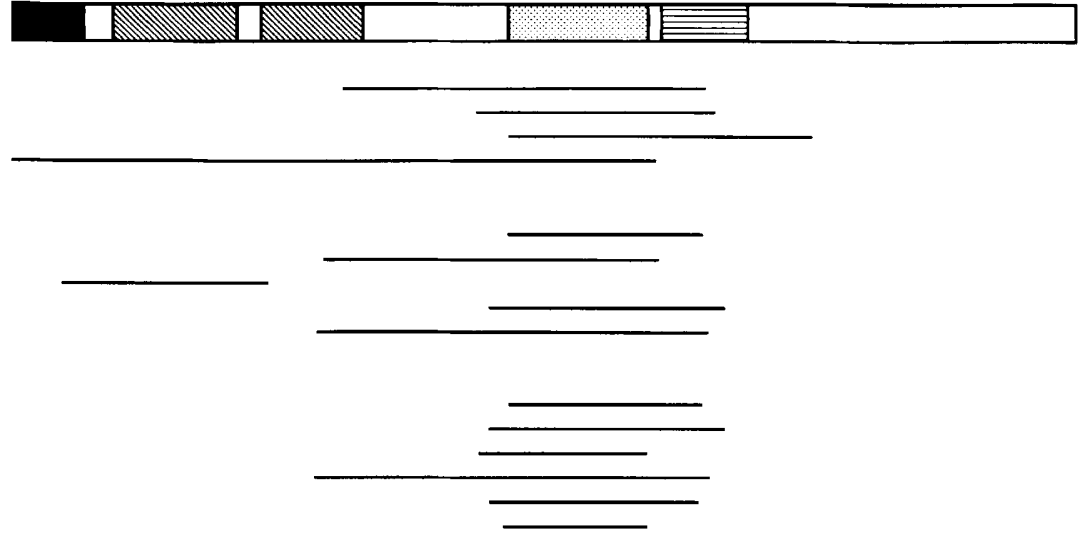

(d)

IVRHDERVKSANDAISKLNEKDSIENRRLAQREVNKAPMDVKEHLQKQLDALVAQKDA

Fig. 1. Schematic drawing of protein Sbi aligned with the polypeptides isolated by panning. (a) Clones isolated after panning a library made from staphylococcal chromosomal DNA against NCS (Jacobsson \& Frykberg, 1998). (b, c) Panning of an sbi gene fragment library against serum and $\beta_{2}$-GPI, respectively. Amino acids (aa) show the exact position of the peptides in protein Sbi (Zhang et al., 1998). Black box, signal peptide; first hatched box, IgG-binding domain; second hatched box, putative IgG-binding domain; dotted box, $\beta_{2}$-GPI-binding domain; striped box, proline repeat region. (d) Amino acid sequence of the minimal $\beta_{2}$-GPI-binding domain deduced by phage display.

were ${ }^{125}$ I-labelled using the IODO-BEADS Iodination Reagent kit (Pierce) according to the manufacturer's instructions.

Cells from overnight cultures were collected by centrifugation and washed in PBS-D. One hundred microlitres of ${ }^{125} \mathrm{I}$-labelled $\beta_{2}$-GPI (approx. 65000 c.p.m., specific activity $1 \cdot 1 \times 10^{6}$ c.p.m. $\mu \mathrm{g}^{-1}$ ) or $100 \mu \mathrm{l}$ labelled anti-Sbi antibodies (approx. 125000 c.p.m., specific activity $1 \cdot 2 \times 10^{6}$ c.p.m. $\mu \mathrm{g}^{-1}$ ) in PBS-T with $0 \cdot 1 \%(\mathrm{w} / \mathrm{v})$ BSA was mixed with $5 \times 10^{8}$ cells and incubated at room temperature for $1 \mathrm{~h}$. The cells were pelleted and washed three times in PBS-T with $0 \cdot 1 \%(\mathrm{w} / \mathrm{v})$ BSA. Finally, the radioactivity of the pellets was measured in an LKB gamma counter.

\section{RESULTS}

\section{Isolation of the second serum protein bound by protein Sbi}

Earlier results suggested that protein Sbi binds a second serum component in addition to $\operatorname{IgG}$ (Jacobsson \& Frykberg, 1998). This component has now been isolated from NCS on an affinity matrix containing a truncated protein Sbi lacking the IgG-binding domain (MALSbis; Zhang et al., 1998). The eluted proteins were concentrated by lyophilization and analysed by SDSPAGE under non-reducing conditions. Staining with Coomassie blue showed one major protein of about $50 \mathrm{kDa}$ (Fig. 2a, lane 3). N-terminal sequencing of this protein gave the peptide sequence Gly-Arg-Thr-CysPro-Lys-Pro-Asp. Homology searches showed that this sequence was identical to the $\mathrm{N}$-terminus of the mature $\beta_{2}$-GPI. The molecular mass of bovine $\beta_{2}$-GPI deduced from the nucleotide sequence (Gao et al., 1993) is $36 \mathrm{kDa}$, but is reported to migrate at approximately $50 \mathrm{kDa}$ in SDS-PAGE, which agrees well with the size of the protein we isolated from NCS. A protein of similar size could also be purified from human and rat serum.

The identity of the purified proteins was confirmed using antibodies directed against human $\beta_{2}$-GPI. Fig. 2 (b) shows that the proteins affinity-purified from the three different sera (lanes 2-4) and the commercially available human $\beta_{2}$-GPI (lane 5) are recognized by a polyclonal antibody against human $\beta_{2}$-GPI. Fig. 2(c) shows an identical blot incubated with the MAL-Sbi fusion protein, which was detected with HRP-labelled antibodies against protein Sbi.

In both Western blots, a second larger protein is visible in the commercially available human $\beta_{2}$-GPI (Fig. $2 \mathrm{~b}, \mathrm{c}$, lane 5) and is believed to be a dimer. A second, significantly larger protein, is also visible in the $\beta_{2}$-GPI purified from human serum (Fig. 2b, c, lane 4). This protein is stronger in the blot detected with the MAL-Sbi fusion protein (Fig. 2c) than in the one detected with antibodies against human $\beta_{2}$-GPI (Fig. 2b). This protein is most likely either a complex of $\beta_{2}$-GPI and an unidentified serum component co-purified with $\beta_{2}$-GPI, or a multimer of $\beta_{2}$-GPI. A protein of the same size is also visible on the Coomassie-blue-stained gel after purification from rat serum (Fig. 2a, lane 2), but is not recognized by either the $\mathrm{MAL}-\mathrm{Sbi}$ fusion protein or the polyclonal antibody in Western blots (Fig. 2b,c). Strangely, the larger component purified from human serum, but not from rat serum, reacts strongly with the MAL-Sbi protein. In contrast, the antibodies against $\beta_{2}$ GPI react only weakly with the larger protein band. However, from bovine serum only one form of the protein was obtained after affinity purification on protein Sbi. 
(a)

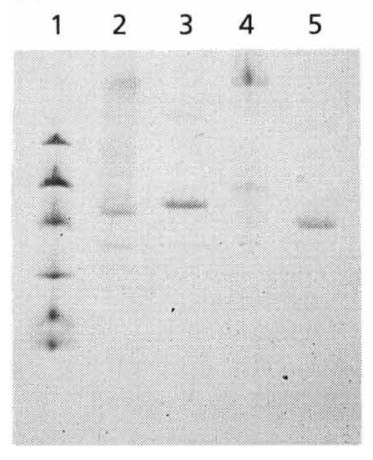

(b)

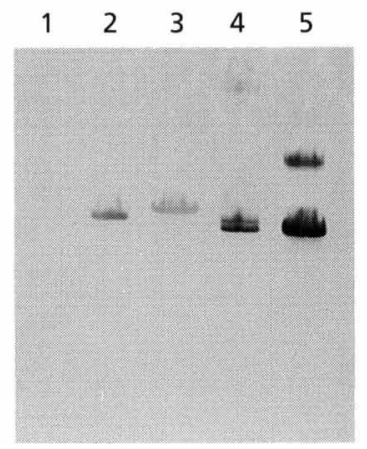

(c)

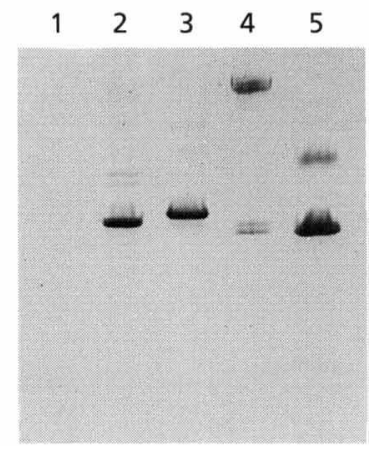

Fig. 2. Purification of $\beta_{2}$-GPI from different mammalian sera. (a) SDS-PAGE. Also shown are Western blots detected with (b) polyclonal antibodies against human $\beta_{2}$-GPI and (c) MAL-Sbi as described in Methods. Lanes: 1, size marker (97.4, 66.2, $45.0,31.0,21.5$ and $14.4 \mathrm{kDa}) ; 2, \beta_{2}$-GPI purified from rat serum; $3, \beta_{2}$-GPI purified from bovine serum; $4, \beta_{2}$-GPI purified from human serum; 5 , commercially available human $\beta_{2}$-GPI (ICN).

Table 1. Specific binding of phage displaying the $\beta_{2}$-GPIor lgG-binding domain of protein Sbi to different ligands

Data represent the means $\pm S D$ of three parallel experiments.

\begin{tabular}{|lccc|}
\hline Stock & \multicolumn{2}{c|}{$\begin{array}{c}\text { Phagemid particles eluted after panning } \\
\text { against the respective ligand }\left(\mathbf{1 0}^{-2} \times \text { c.f.u. }\right)\end{array}$} \\
\cline { 2 - 4 } & $\boldsymbol{\beta}_{2}$-GPI & IgG & Fibronectin \\
\hline SbiS12 & $3.0 \pm 1 \cdot 9$ & $15000 \pm 2000$ & $\begin{array}{c}8.8 \pm 4 \cdot 0 \\
\text { SbiS13 }\end{array}$ \\
\hline
\end{tabular}

\section{Identification of the $\boldsymbol{\beta}_{\mathbf{2}}$-GPI-binding domain}

The $\beta_{2}$-GPI-binding domain was identified using shotgun phage display. A phage display library was constructed from the cloned $s b i$ gene. The resulting library, consisting of phages expressing different parts of the gene, was panned against human $\beta_{2}$-GPI or bovine serum. By sequencing the inserted DNA in clones obtained after panning and aligning the encoded polypeptides with protein Sbi, the $\beta_{2}$-GPI-binding domain was identified. As shown in Fig. 1, the domain is positioned downstream of the IgG-binding domain and is completely separated from this. Although the panning against NCS was carried out in the presence of free IgG to inhibit the isolation of IgG-binding phage, one clone containing the IgG-binding region (SbiS12) was recovered.

To confirm this result, phage stocks were prepared from two different clones, clone SbiS13 expressing the $\beta_{2}$-GPIbinding region (aa 196-293) and clone SbiS12 expressing the IgG-binding region (aa 20-109). The phage stocks were panned in triplicate against human IgG, $\beta_{2}$-GPI and fibronectin, included as a negative control. The number of eluted phage particles was used as a measure of the ability to bind the respective ligand. As shown in Table 1, phages expressing aa $20-109$ only bind $\operatorname{IgG}$, while phages expressing aa 196-293 only bind $\beta_{2}$-GPI.
Table 2. Binding of ${ }^{125}$-labelled antibodies against protein Sbi or ${ }^{125}$-labelled $\beta_{2}$-GPI to staphylococcal cells

Data represent the means \pm SD of three parallel binding assays.

\begin{tabular}{|lcc|}
\hline Strain & ${ }^{125} \mathrm{I}-\alpha \mathrm{Sbi}$ & ${ }^{125} \mathrm{I}-\boldsymbol{\beta}_{2}$-GPI \\
\hline S. aureus & & \\
$8325-4$ & $1846 \pm 153$ & $1311 \pm 108$ \\
Cowan I & $2951 \pm 164$ & $1459 \pm 5$ \\
Newman 4 & $14018 \pm 352$ & $6305 \pm 75$ \\
Wood 46 & $92 \pm 24$ & $580 \pm 80$ \\
S. epidermidis & & \\
247 & $336 \pm 39$ & $519 \pm 38$ \\
247 with pShX1 & $2061 \pm 34$ & $1043 \pm 12$ \\
\hline
\end{tabular}

\section{Expression of protein Sbi and binding of $\beta_{2}$-GPI to $S$. aureus}

${ }^{125}$ I-labelled $\beta_{2}$-GPI and anti-Sbi antibodies were used to show that protein $\mathrm{Sbi}$ is expressed on the cell surface in different strains of $S$. aureus. The antibodies were developed in chicken since $S$. aureus does not bind chicken IgG. Binding of labelled $\beta_{2}$-GPI to staphylococcal cells required labelling with Bolton + Hunter reagent to avoid reduction of the disulfide bridges in $\beta_{2}$ GPI. In addition, a high concentration of BSA in the binding buffer was required to inhibit non-specific binding, which also has been reported for binding of $\beta_{2}$ GPI to phospholipids (Wurm, 1984). However, the results obtained for the negative control $S$. epidermidis indicate that the background binding of $\beta_{2}$-GPI could not be completely eliminated. The results in Table 2 show that high levels of protein Sbi were found in $S$. aureus strain Newman 4 whereas strains $8325-4$ and Cowan I produced low amounts. Strain Wood 46 did not bind more antibodies or $\beta_{2}$-GPI than the negative control, S. epidermidis strain 247. However, $S$. epidermidis strain 247 harbouring a shuttle plasmid containing the sbi gene (pShX1) expressed similar 
amounts of protein Sbi as strains $8325-4$ and Cowan I (Table 2).

\section{DISCUSSION}

Using immobilized protein Sbi, the second interacting serum component has now been purified from bovine serum and identified as $\beta_{2}$-GPI by $\mathrm{N}$-terminal amino acid sequencing. The identity has further been confirmed with polyclonal antibodies against $\beta_{2}$-GPI. As shown in Fig. 2, both commercially available $\beta_{2}$-GPI and $\beta_{2}$-GPI purified by affinity chromatography on protein Sbi are recognized by the antibodies against $\beta_{2}$-GPI and by protein Sbi. All SDS-PAGE was run under non-reducing conditions as preceding experiments showed that, in a Western blot, protein Sbi did not recognize the purified proteins and the polyclonal antibodies only showed a weak binding, after electrophoresis under reducing conditions (data not shown). This was not unexpected since $\beta_{2}$-GPI contains 11 disulfide bonds (Kato \& Enjoyji, 1991; Bendixen et al., 1992), which points at the importance of the secondary structure for the recognition by protein Sbi. A similar observation was reported by Mehdi et al. (1994), who found that treatment of $\beta_{2}$-GPI with a reducing agent destroyed the ability to bind to a recombinant hepatitis $B$ surface antigen.

Alignment with protein Sbi of the polypeptides expressed by the phage display clones obtained after panning against NCS or $\beta_{2}$-GPI shows one $\beta_{2}$-GPIbinding domain. This domain is located downstream of the IgG-binding domain and is clearly separated from this (Fig. 1). The minimal $\beta_{2}$-GPI-binding domain deduced from isolated clones consists of $57 \mathrm{aa}$, similar in size to the minimal IgG-binding domain (52 aa) identified earlier. Immediately downstream of the IgG-binding domain there is a region with homology to the IgGbinding repeats in protein $\mathrm{A}$, but no IgG-binding clones covering only this region were isolated (Zhang et al., 1998). Four clones isolated after panning against serum and $\beta_{2}$-GPI (NCS17, SbiS8, SbiS27 and SbiA96) extend approximately 70 aa further upstream than the majority of the clones (Fig. 1). This suggests that an extended Nterminus may contribute to a more favourable conformation that increases the affinity for $\beta_{2}$-GPI, or may even indicate the presence of a second $\beta_{2}$-GPI-binding domain. Thus, it can not be excluded that protein Sbi contains two IgG- and two $\beta_{2}$-GPI-binding domains, but with a difference in affinity for the respective ligand, which would explain why only one domain is isolated by shotgun phage cloning.

This is the first report of a bacterial protein that binds the serum glycoprotein $\beta_{2}$-GPI. Although $\beta_{2}$-GPI was described in 1961 and despite its rather high concentration in serum $\left(0.15-0.30 \mathrm{mg} \mathrm{m}^{-1}\right)$ (Cleve \& Rittner, 1969), the biological function is not clear. The protein binds to negatively charged substances such as heparin, dextran sulfate and phospholipids. $\beta_{2}$-GPI is structurally related to regulators of the complement system, and consists of five repetitive domains, four of which contain a motif called the complement control protein repeat or Sushi-domain (Kato \& Enjoyji, 1991; Steinkasserer et al., 1991; Bendixen et al., 1992). $\beta_{2}$-GPI has been reported to have several biological functions when bound to negatively charged lipids, such as promoting clearance of liposomes and maybe foreign particles from the bloodstream (Chonn et al., 1992) and inhibiting blood coagulation by affecting the prothrombinase activity of, for example, non-activated or lysed platelets (Nimpf et al., 1986). The relevance of the staphylococcal- $\beta_{2}$-GPI interaction in vivo is not obvious. It is possible that bacteria in wounds can benefit from inhibition of the blood clotting. In addition, the interaction of cell-wall-bound $\beta_{2}$-GPI with negatively charged lipid membranes may be a means for attachment to host cells or entering cells for intracellular growth of the staphylococci.

$\beta_{2}$-GPI has attracted a lot of attention during the last decade since it has been implicated to be involved in the development of autoimmune disease. For example, in anti-phospholipid antibody syndrome (APS), the autoimmune antibodies are often not directed against phospholipids alone, but against phospholipids bound to $\beta_{2}$-GPI or $\beta_{2}$-GPI alone (Galli et al., 1990; McNeil et al., 1990; Verrier Jones et al., 1992). It is not known what causes the induction of these antibodies but it has been suggested that a change in conformation of $\beta_{2}$-GPI may be responsible. Interestingly, anti-phospholipid antibodies (aPL) can be induced by immunization with heterologous $\beta_{2}$-GPI (Pierangeli \& Harris, 1989; Gharavi et al., 1992, 1995; Aron et al., 1995; García et al., 1997). Phospholipids as such are poor immunogens, but when coupled to a carrier such as BSA or $S$. aureus cells, they can induce production of aPL (Rauch et al., 1984). Thus, it is tempting to speculate that $S$. aureus infections may be one of the mechanisms for induction of APS. The bacteria may simply act as a carrier of $\beta_{2}$ GPI and trigger the production of aPLs. Alternatively, the binding of $\beta_{2}$-GPI to protein Sbi might cause a conformational change in $\beta_{2}$-GPI which activates the immune response.

The biological importance of protein Sbi in the virulence of $S$. aureus has not yet been determined. IgG binding is found in virtually all $S$. aureus strains and has been considered to be important for virulence. Still, S. aureus mutants lacking protein A were only slightly less virulent than the parental strain (Jonsson et al., 1985; Patel et al., 1987). The fact that protein Sbi binds both IgG and $\beta_{2}$ GPI increases the likely importance of Sbi in virulence.

PCR analysis with a single primer pair has shown that the $s b i$ gene was present in 28 of 29 human clinical isolates (data not shown). In addition, using antibodies against protein Sbi expression levels similar to that of strain $8325-4$ were detected in 23 of the 24 isolates tested (data not shown). Thus, in general the expression level of protein Sbi is low. Interestingly, strain Newman 4, originally isolated as a spontaneous mutant of strain Newman that expresses high levels of fibronectinbinding proteins, also is high in expression of protein $\mathrm{Sbi}$, indicating a common regulatory mechanism. 
Further investigation of the regulation of protein Sbi expression is under way.

\section{ACKNOWLEDGEMENTS}

We thank Bo Ek at the Department of Cell Research, SLU, for the N-terminal amino acid sequencing and Bertil Christensson, University of Lund, for supplying the clinical isolates. The investigation was supported by grants from the Swedish Research Council for Engineering Sciences (94-380 and 96-759), the Swedish Medical Research Council (16X03778) and the Immunotechnology program founded by the Swedish National Board for Industrial and Technical Development (P2355-1).

\section{REFERENCES}

Aron, A. L., Cuellar, M. L., Brey, R. L., Mckeown, S., Espinoza, L. R., Shoenfeld, Y. \& Gharavi, A. E. (1995). Early onset of autoimmunity in $\mathrm{MRL} /++$ mice following immunization with $\beta_{2}$ glycoprotein I. Clin Exp Immunol 101, 78-81.

Bendixen, E., Halkier, T., Magnusson, S., Sottrup-Jensen, L. \& Kristensen, T. (1992). Complete primary structure of bovine $\beta_{2}-$ glycoprotein I: localization of the disulfide bridges. Biochemistry 31, 3611-3617.

Bolton, A. E. \& Hunter, W. M. (1973). The labelling of proteins to high specific radioactivities by conjugation to a ${ }^{125}$ I-containing acetylating agent. Biochem J 133, 529-539.

Chonn, A., Semple, S. C. \& Cullis, P. R. (1992). Association of blood proteins with large unilamellar liposomes in vivo. $\mathrm{J} \mathrm{Biol}$ Chem 267, 18759-18765.

Cleve, H. \& Rittner, C. (1969). Further studies on the genetic control of beta 2-glycoprotein I concentration in human serum. Humangenetik 7, 93-97.

Cunningham, R., Cockayne, A. \& Humphreys, H. (1996). Clinical and molecular aspects of the pathogenesis of Staphylococcus aureus bone and joint infections. J Med Microbiol 44, 157-164.

Galli, M., Comfuruis, P., Maassen, C., Hemker, H. C., de Baets, M. H., van Breda-Vriesman, P. J., Barbui, T., Zwaal, R. F. \& Bevers, E. M. (1990). Anticardiolipin antibodies (ACA) directed not to cardiolipin but to a plasma protein cofactor. Lancet 335, 1544-1547.

Gao, B., Virmani, M., Romm, E., Lazar-Wesley, E., Sakaguchi, K., Appella, E., Kunos, G. \& Takács, L. (1993). Sequence of a cDNA encoding bovine apolipoprotein H. Gene 126, 287-288.

García, C. O., Kanbour-Shakir, A., Tang, H., Molina, J. F., Espinoza, L. R. \& Gharavi, A.E. (1997). Induction of experimental antiphospholipid antibody syndrome in $\mathrm{PL} / \mathrm{J}$ mice following immunization with $\beta_{2}$ GPI. Am J Reprod Immunol 37, 118-124.

Gharavi, A. E., Sammaritano, L. R., Wen, J. \& Elkon, K. B. (1992). Induction of antiphospholipid autoantibodies by immunization with $\beta 2$ glycoprotein I (apolipoprotein $\mathrm{H}$ ). J Clin Invest 90 , 1105-1109.

Gharavi, A. E., Sammaritano, L. R., Bovastro, J. L. \& Wilson, W. A. (1995). Specificities and characteristics of $\beta_{2}$ glycoprotein Iinduced antiphospholipid antibodies. $J$ Lab Clin Med 125, $775-778$.

Jacobsson, K. \& Frykberg, L. (1995). Cloning of ligand-binding domains of bacterial receptors by phage display. BioTechniques $18,878-885$.

Jacobsson, K. \& Frykberg, L. (1996). Phage display shotgun cloning of ligand-binding domains of prokaryotic receptors approaches $100 \%$ correct clones. BioTechniques 20, 1070-1081.
Jacobsson, K. \& Frykberg, L. (1998). Gene VIII-based phage display vectors for selection against complex mixtures of ligands. Bio'Techniques 24, 294-301.

Jönsson, K., Signäs, C., Müller, H.-P. \& Lindberg, M. (1991). Two different genes encode fibronectin binding proteins in Staphylococcus aureus. The complete nucleotide sequence and characterization of the second gene. Eur J Biochem 202, 1041-1048.

Jonsson, P., Lindberg, M., Haraldsson, I. \& Wadström, T. (1985). Virulence of Staphylococcus aureus in a mouse mastitis model: studies of alpha hemolysin, coagulase, and protein A as possible virulence determinants with protoplast fusion and gene cloning. Infect Immun 49, 1021-1030.

Kato, H. \& Enjoyji, K. (1991). Amino acid sequence and location of the disulfide bonds in bovine $\beta 2$ glycoprotein I: the presence of five Sushi domains. Biochemistry 30, 11687-11694.

Kronvall, G., Quie, P. G. \& Williams, R. C., Jr (1970). Quantification of staphylococcal protein A: determination of equilibrium constant and number of protein A residues on bacteria. J Immunol 104, 140-147.

McNeil, H. P., Simpson, R. J., Chesterman, C. N. \& Krilis, S. A. (1990). Anti-phospholipid antibodies are directed against a complex antigen that includes a lipid-binding inhibitor of coagulation: $\beta_{2}$-glycoprotein I (apolipoprotein $\mathrm{H}$ ). Proc Natl Acad Sci USA 87, 4120-4124.

Mehdi, H., Kaplan, M. J., Anlar, F. Y., Yang, X., Bayer, R., Sutherland, K. \& Peeples, M. E. (1994). Hepatitis B virus surface antigen binds to apolipoprotein H. J Virol 68, 2415-2424.

Nimpf, J., Bever, E. M., Bomans, P. H. H., Till, U., Wurm, H., Kostner, G. M. \& Zwaal, R. F. A. (1986). Prothrombinase activity of human platelets is inhibited by $\beta_{2}$-glycoprotein I. Biochim Biophys Acta 884, 142-149.

Novick, R. P. (1967). Properties of a cryptic high-frequency transducing phage in Staphylococcus aureus. Virology 33, 155-156.

Patel, A. H., Nowlan, P., Weavers, E. D. \& Foster, T. J. (1987). Virulence of protein A-deficient and alpha-toxin deficient mutants of Staphylococcus aureus isolated by allele replacement. Infect Immun 55, 3101-3110.

Pierangeli, S. S. \& Harris, E. N. (1989). Induction of phospholipidbinding antibodies in mice and rabbit by immunization with human $\beta_{2}$-glycoprotein I or anticardiolipin antibodies alone. Clin Exp Immunol 78, 233-238.

Rauch, J., Tannenbaum, H., Stollar, B. D. \& Schwartz, R. S. (1984). Monoclonal anti-cardiolipin antibodies bind to DNA. Eur $J$ Immunol 14, 529-534.

Rosendorf, L. L. \& Kayser, F. H. (1974). Transduction and plasmid deoxyribonucleic acid in a multiply antibiotic resistant strain of Staphylococcus epidermidis. J Bacteriol 120, 679-686.

Sambrook, J., Fritsch, E. F. \& Maniatis, T. (1989). Molecular Cloning: a Laboratory Manual, 2nd edn. Cold Spring Harbor, NY: Cold Spring Harbor Laboratory.

Steinkasserer, A., Estaller, C., Weiss, E. H., Sim, R. B. \& Day, A. J. (1991). Complete nucleotide and deduced amino acid sequence of human $\beta_{2}$-glycoprotein I. Biochem J 277, 387-391.

Swartz, M. N. (1994). Hospital-acquired infections: diseases with increasing limited therapies. Proc Natl Acad Sci USA 91, 2420-2427.

Uhlén, M., Guss, B., Nilsson, B. G., Gatenbeck, S., Philipsson, L. \& Lindberg, M. (1984). Complete sequence of the staphylococcal gene encoding protein $\mathrm{A}$, a gene evolved through multiple duplications. J Biol Chem 29, 1695-1702.

Verrier Jones, J., James, H., Tan, M. H. \& Mansour, M. (1992). 
Antiphospholipid antibodies require $\beta_{2}$-glycoprotein I (apolipoprotein $\mathrm{H}$ ) as cofactor. J R heumatol 19, 1397-1402.

Wertman, K. F., Wyman, A. R. \& Botstain, B. (1986). Host/vector interactions which affect the viability of recombinant phage lambda clones. Gene 49, 253-262.

Wurm, H. (1984). $\beta_{2}$-glycoprotein I (apolipoprotein $H$ ) interactions with phospholipid vesicles. Int J Biochem 16, 511-515.
Zhang, L., Jacobsson, K., Vasi, J., Lindberg, M. \& Frykberg, L. (1998). A second IgG-binding protein in Staphylococcus aureus. Microbiology 144, 985-991.

Received 10 July 1998; revised 1 September 1998; accepted 30 September 1998. 